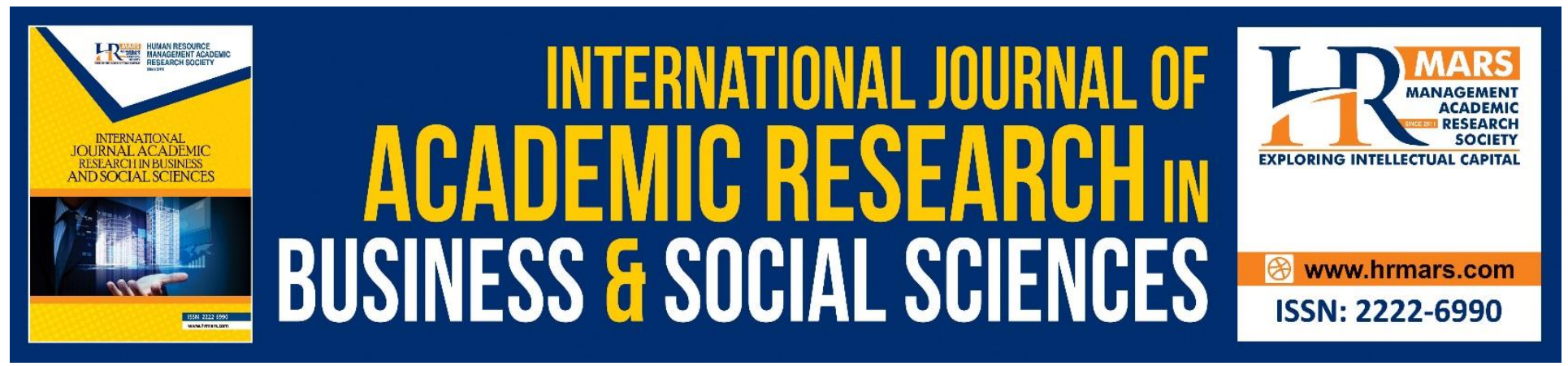

\title{
Leaky Pipeline Syndrome in Information and Communication Technology (ICT) Industry of Malaysia: A Conceptual Study on Female Career Barriers and Retention Management
}

Manimegalai Rajenderan, Dahlia Zawawi

To Link this Article: http://dx.doi.org/10.6007/IJARBSS/v9-i2/5672

DOI: $\quad 10.6007 /$ IJARBSS/v9-i2/5672

Received: 14 Jan 2019, Revised: 21 Feb 2019, Accepted: 26 Feb 2019

Published Online: 09 March 2019

In-Text Citation: (Rajenderan \& Zawawi, 2019)

To Cite this Article: Rajenderan, M., \& Zawawi, D. (2019). Leaky Pipeline Syndrome in Information and Communication Technology (ICT) Industry of Malaysia: A Conceptual Study on Female Career Barriers and Retention Management. International Journal of Academic Research in Business and Social Sciences, 9(2), 1158-1174.

Copyright: (C) 2019 The Author(s)

Published by Human Resource Management Academic Research Society (www.hrmars.com)

This article is published under the Creative Commons Attribution (CC BY 4.0) license. Anyone may reproduce, distribute, translate and create derivative works of this article (for both commercial and non-commercial purposes), subject to full attribution to the original publication and authors. The full terms of this license may be seen

at: http://creativecommons.org/licences/by/4.0/legalcode

Vol. 9, No. 2, 2019, Pg. 1158 - 1174

http://hrmars.com/index.php/pages/detail/IJARBSS

JOURNAL HOMEPAGE

Full Terms \& Conditions of access and use can be found at http://hrmars.com/index.php/pages/detail/publication-ethics 


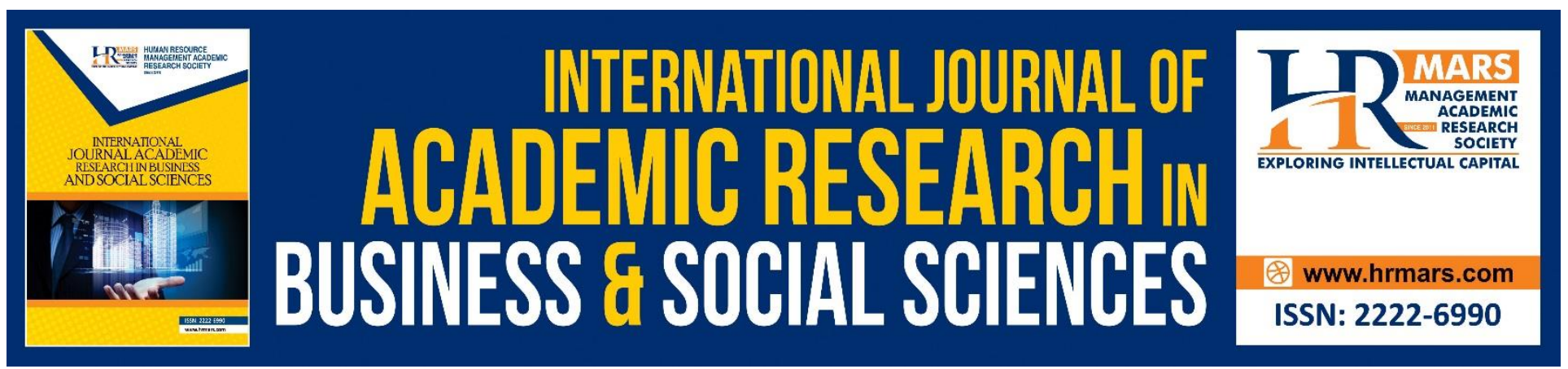

\title{
Leaky Pipeline Syndrome in Information and Communication Technology (ICT) Industry of Malaysia: A Conceptual Study on Female Career Barriers and Retention Management
}

\author{
Manimegalai Rajenderan \\ Putra Business School, University Putra Malaysia, 43400 Serdang, Selangor, Malaysia
}

\section{Dahlia Zawawi}

Faculty of Economics and Management, University Putra Malaysia Malaysia, 43400 Serdang, Selangor, Malaysia

\begin{abstract}
In Malaysia, women accounted more university enrolments then men in computer majors and occupy about half of the jobs in Science \& Technology in Malaysia. While the number of women graduates has been increasing, their employment attrition rate compared women have been significantly higher in ICT industry, this problem has often been called the "leaky pipeline" syndrome. It is posited that given the current labor shortage in the ICT industry; it has become more important than ever to reduce sources of leakage in the ICT career paths of women. A model of barriers faced by women in the field of ICT is presented herein. Female career barriers such as work-family conflict, technostress and mentorship were identified and discussed in this paper. Subsequently, this paper suggested that these identified barriers tend to implicate psychological well-being, which is the key determinant for female talent's retentiveness in ICT industry. The finding of the study able to provide appropriate patch for the leakage in the women's ICT career pipeline.

Keywords: Leaky Pipeline Syndrome, Work-Family Conflict, Technostress, Mentorship, Psychological Well-Being and Retention

\section{Introduction}

The Information Technology (IT) industry is now commonly known as the Information and Communications Technology (ICT) industry with the entry of the telecommunications sector (The National ICT Association of Malaysia, 2017). The rapid growth of the ICT sector, supported by the accelerated development of computing capacity and internet delivered goods and services, has seen
\end{abstract}


a steadily expanding body of research examining this sector and its workforce (Benner 2002, Hyde 2003, McKeown, Veenhof and Corman 2008, Niederman \& Ferratt 2006, Ross 2009, Tremblay 2003, Valgaeren 2008). The ICT job market in Malaysia in 2017 showed improvement in salary growth and higher number of jobs compared to 2016. The overall average monthly salary of ICT Professionals grew to RM8,908 in 2017, a 5\% growth from RM8,484 in 2016. This was a better growth compared to $4.6 \%$ in 2016 . The number of advertised jobs for ICT professionals jumped by $35 \%$ to 15,197 in 2017 compared with 11, 227 in 2016. These were among the findings in the 11th edition of the Pikom ICT Job Market Outlook in Malaysia 2018 launched on July, 2018. Despite the tremendous growth in ICT sector, a number of Human Resource Management (HRM) issues emerged as key themes in this research, including the issue of relatively high labor turnover rates. The National ICT Association of Malaysia (2017), reported the main 3 problems were foreseen in ICT industry in Malaysia which are 1) a lack of skilled professionals, 2) the drop-in women in the workforce and 3) the mismatch of talents has been long-standing issues for nearly two decades. This study going to evaluate further on the 2 nd problem, which is drop in women talent in ICT sector.

TalentCorp Malaysia and The National ICT Association of Malaysia (2017) reported that the problem is not only in attracting women into ICT sector, but also in retaining them. Women remain severely underrepresented in the ICT profession globally. While the number of women graduates has been increasing, their employment attrition rate compared to men has been significantly higher in IT industry, this problem has often been called the "leaky pipeline" syndrome (Smith \& Swamy, 2016). Female workers, who comprise half of Malaysia's talent pool, are seen exiting the workforce in their late 20 s to early 30 s in the prime of their careers due to family commitments and do not typically return to the workforce in their later years, unlike peers in Japan and South Korean. According to World Bank research, the participation rate of Malaysian women in the workforce stands at $46 \%$, considerably lower compared to its ASEAN peers and other countries like Japan and South Korean with similar development and income levels. While qualified women may join the workforce in larger numbers at the beginning of their careers, mid-path their numbers begin to decline as they quit formal employment (TalentCorp Malaysia \& ACCA, 2013).

Women are nearly two and a half times more likely than men to leave the ICT labor force and reach a career 'breaking point' in their mid to late 30s which has resulted in 52\% of highly qualified SET (Science, Engineering \& Technology) women quitting their jobs (Trauth, Quesenberry, \& Huang, 2006). The growth of information technology industry created the need of new skills, innovation and creativity hence talented women are leaving the sector, despite its apparent attractiveness. This conditions must be assessed within the context of Malaysian social values to determine the appropriate policy environment and incentives to retain a larger proportion of women in the labor force especially after marriage (Ahmad, 1998).

A search of the literature concerned with the retention of female ICT professionals in particular was carried out and a number of key factors identified by means of content analysis. Several factors that have an influence on retention have been identified by previous research (Kyndt, Dochy, Michielsen, \& Moeyaert, 2009). However, according to Cardy and Lengnick-Hall (2011) there are "a myriad of other factors" that influence decisions to stay (p. 213). Therefore, the aim of this study is to identify 
INTERNATIONAL JOURNAL OF ACADEMIC RESEARCH IN BUSINESS AND SOCIAL SCIENCES

Vol. 9, No. 2, Feb, 2019, E-ISSN: $2222-6990$ ๑ 2019 HRMARS

career barriers and factors that influence retention of female ICT professionals in Malaysia, hence gives fruitful impact in realizing nation goals in creating gender balanced labor force in technological field.

\section{The Leaky Pipeline Syndrome in Malaysia ICT Industry}

A leaky pipeline is often cited as the cause for the underrepresentation of women in computerrelated professions. At different stages in their education and entrance into the job market, women lose interest in these careers at a higher rate than do men, leaving the field after high school, during college, or before beginning a job in the field (Gurer \& Camp, 2002; Woszczynski, Myers, \& Beise, 2003). Proponents of the "leaky pipeline" theory generally assert that female interest in technology decreases through college student and early working years (Gurer \& Camp, 2002). However, it seems that females might not be leaking from the pipeline at greater rates than males; instead, they might not be entering the pipeline at all. At each stage of advancement, fewer women succeed to the next position is analogous to the "leaks" in the pipeline (Campbell, 2015).

Sue Berryman's report Who will do science? Minority and Female attainment of science and mathematics degrees: Trends and Causes (1983) has made an important contribution to the theoretical and political debates in the UK about women's representation in science occupations. Berryman introduced the 'pipeline model', based on an empirical analysis of gender differences across the entire trajectory of training and employment rather than on discrete educational and career stages. By conceptualizing the scientific career as the sections of a narrowing pipeline, Sue Berryman's model concisely and visually describes where leakages of female scientists leaving the pipeline occur and the volume decreases leading to shortages in female supply (Berryman, 1983). Eventually the pipeline model has been used as foundation to study other technical fields as technology, engineering and mathematics (Lehr, 2001).

Ministry of Higher Education (MOHE) in 2010, conducted "Graduate Tracer Study" and stated that the overall ratio of female to male graduates for various Information \& Communications Technology (ICT) fields at various public and private institutions of higher learning was 1.04:1. This means that there is nearly a 1-to-1 ratio in schools and in fact, the number of female ICT graduates is marginally more than that of male ICT graduates. In year 2014, Malaysia Digital Economy Corporation (MDEC) conducted a study of MSC Malaysia Talent Supply-Demand Study of 2010-2013. The study reveals that the number of male and female students across all the Institute of Higher learning (IHL) respondents are equally divided, with a higher proportion of females in IPTA (58\%) while IPTS, polytechnic and community college have more male students (58\%).

Table 1. Gender Breakdown in IHL (2013-2017)

\begin{tabular}{|l|c|c|}
\hline Institute Higher Leaning & Male & Female \\
\hline IPTA & $42 \%$ & $58 \%$ \\
\hline IPTS & $58 \%$ & $42 \%$ \\
\hline Polytechnic and community college & $57 \%$ & $43 \%$ \\
\hline
\end{tabular}

Source: Malaysia Digital Economy Corporation (MDEC) 
In terms of fields of study, there are more females taking up IT courses in IPTA and polytechnic / community college ( $60 \%)$, while Engineering is dominated by male students across all IHLs.

Figure 2.2 Gender breakdown in IHL (2013-2017)
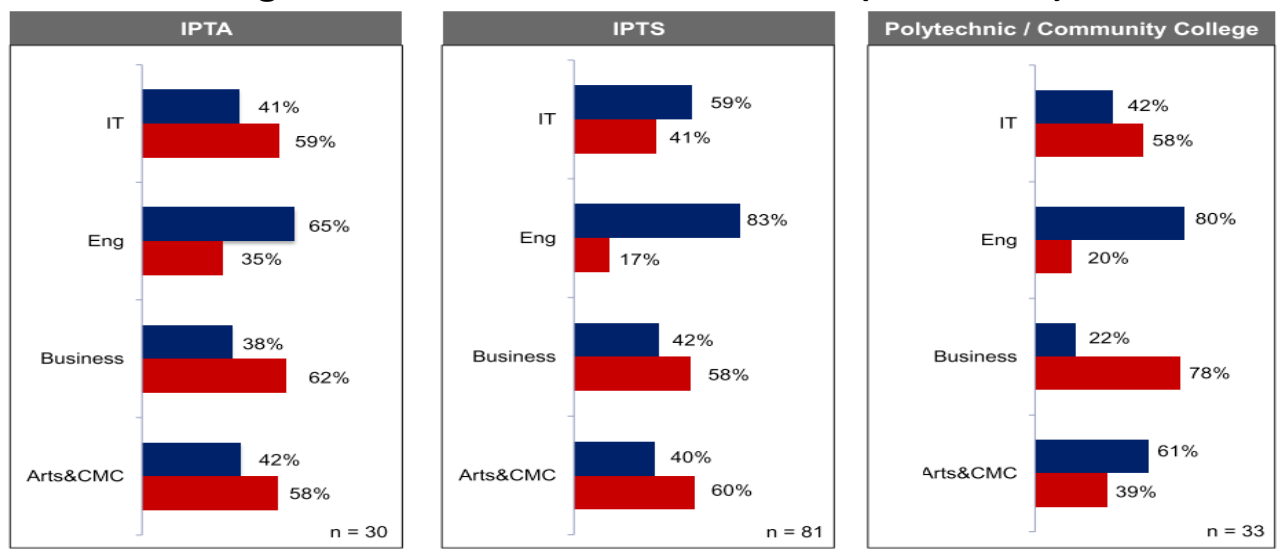

Male $\square$ Female

Source: Malaysia Digital Economy Corporation (MDEC)

Although female enrollments and graduation in ICT courses is marginally hinger than male, however female workforce in ICT industry is severely underrepresented as reported by Graduate Tracer Study (2016), by Ministry of Higher Education (MOHE), where total of 10,816 male employee and total of 9,645 female employee currently employed in ICT field in Malaysia. Overall out of $60 \%$ of female ICT enrolment only $3.3 \%$ women are in scientific and technological careers stated by Ministry of Women, Family and Community Development Malaysia (2013).

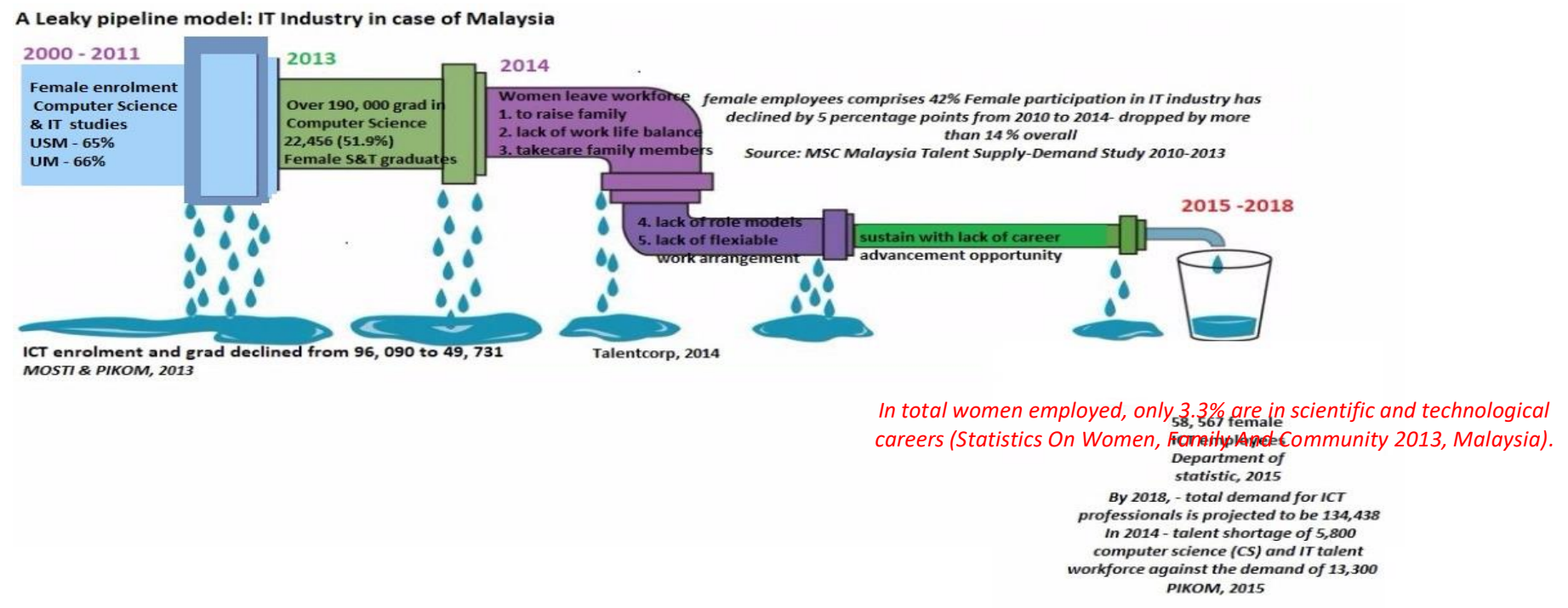

Figure 1. Leaky pipeline in model: ICT industry of Malaysia

Adapted from www.businessandeducation.org 
Vitalari \& Dell (1998) have reported that the cost of filling a vacancy is as high as $120 \%$ of the yearly salary for the position. In this environment, 'women may prove to be a key resource of skilled technology workers for international IT markets' (Maitland, 2001, p 9). However, despite a host of efforts to attract and keep women and minorities in computing, their retention continues to be a significant challenge in computer-related disciplines (Pfleeger \& Mertz, 1995). As a result, more and more companies are reassessing practices that may lead to turnover, including those related to balancing family and work life (Goff, 2000). Under these circumstances, it has become more important than ever to identify factors affecting women in ICT careers that may act as sources of leakage in the pipeline of ICT career paths. Once identified, these barriers can be addressed with appropriate intervention.

\section{Self-Determination Theory (SDT)}

Self-Determination Theory (SDT) is an evidence-based theory of motivation created by Edward Deci and Richard Ryan and developed by researchers worldwide. It posits that there are two main types of motivations as intrinsic and extrinsic, that both are powerful forces in shaping who we are and how we behave (Deci \& Ryan, 2008). According to self-determination theory (SDT), there are three fundamental, intrinsic psychological needs that are required for optimal functioning and well-being (Gagne \& Deci, 2005). These needs are autonomy, competence, and relatedness (See table 4.3). Autonomy refers to the perception that the individual has choice with regard to his/her own behavior and decisions; competence refers to engagement in challenging experiences and the belief that the individual can bring about desired outcomes; and relatedness refers to the experience of connection and belonging with others (Gagne \& Deci, 2005; Howell, Chenot, Hill, \& Howell, 2011). Importantly, SDT posits that the experience of autonomy, competence, and relatedness are "universal necessities" (p. 337,(Gagne \& Deci, 2005) and that satisfaction of these needs improves psychological health while thwarting these needs can be harmful. Indeed, past research on psychological need fulfillment supports such a mediation model. For example, need fulfillment has been shown to mediate the relationship between perceptions of organizational and supervisor support with both subjective wellbeing (SWB) and psychological well-being (PWB) (Gillet, Fouquereau, Forest, Brunault, \& Colombat, 2012) . It is suggested in the present study that the extent to which these needs are met would motivate female ICT professionals in order to mitigate career barriers, gain positive psychological well-being and achieve retention in technological career for long run.

\section{Female Career Barriers Model}

Igbaria \& Baroudi (1995), given call for future researchers to explore the potential barriers to promotability among women have aspiration to excel in ICT career path. Hence, discovering the reason for such barriers existed and possible way to overcome them is biggest contribution for the literature. In conjunction to that, this study identified the most prevalent female career barriers such as work-family conflict, technostress and mentorship which are highly impact psychological wellbeing of female employees in ICT professions. Female career barriers often implicate psychological well-being of female employees (Martire et al., 2000). Withstanding to that, this study going to answer what is the level of female employee's psychological well-being in Malaysian society and how 
they could handle these foreseen barriers in vital way in order to archive job retention in technological field for long run.

This paper proposes a model of barriers faced by women that affect their entry and performance in the ICT field. The model examines effects of barriers on women's psychological well-being and its influence on job retention in ICT careers. It is suggested that each of these barriers can serve as a source of leakage in the pipeline, and make a cumulative contribution to the ICT labor shortage. It is suggested that it is not sufficient to examine these factors in isolation from one another, as the ICT literature on gender has done so far. In order to develop a rich understanding of ICT careers, it is crucial that inter- actions among these factors be considered.

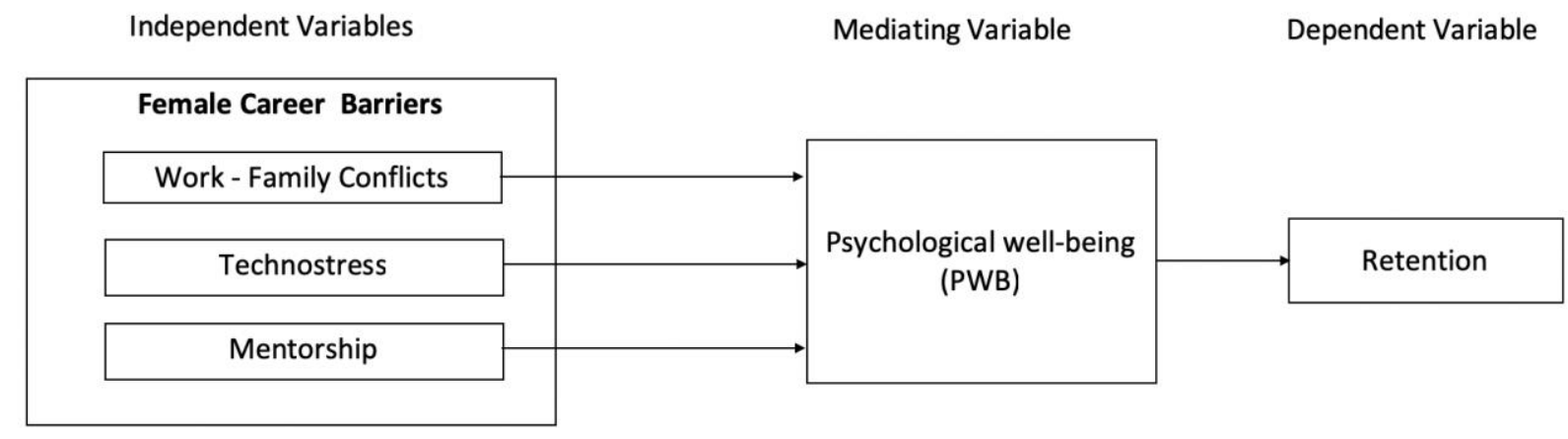

Figure 1. Conceptual Framework

\section{Work - Family Conflict}

Work-family conflict has been defined as "a form of inter-role conflict in which the role pressures from the work and family domains are mutually incompatible is some respect" (Greenhaus \& Beutell, 1985, p. 77). Research on work-family conflict has found that this variable influences a number of outcomes including psychological distress, job satisfaction, organization commitment, turnover, and life satisfaction (Frone, Russell, \& Cooper, 1992; Higgins, Duxbury, \& Irving, 1992; O’Driscoll, Brough, \& Kalliath, (2004); Parasuraman, Greenhaus, Rabinowitz, Bedeian, \& Mossholder, 1989). Thus, workfamily conflict has become a much-investigated topic in today's organizational behavior research.

Work-family interface studies involves varied structural and psychological aspects of work and family life which determine the outcome for the domains namely work, family, and individual (Karimi, 2009). Henceforth, increase research understanding of this interface is essential (Eagle, Miles, \& Icenogle, 1997) due to drastic increase of women participation in labor force globally (Powell \& Graves, 2003). The non-synchronicity in certain aspects of the demand and duties of the work and family roles arises work-family conflict (Greenhaus \& Beutell, 1985). Recent demographic changes in labor force, such as the greater involvement of women and parents in the workplace have led to a proliferation of studies that negative effects of the work-family interface arise due to rising demands on the individuals' time (Aryee, Srinivas, \& Tan, 2005). Over the past century there has been drastic increase of employee turnover rates (Haar, 2004) due to these negative effects. In this thesis, the researcher focuses and accentuate on two domains of the work-family interfaces, which are work-family conflict, and family-work conflict. Many researchers believed that psychological distress induced by work- 
family conflicts tend to compromise well-being and lead poor retention rate in careers. Paying attention to the work family conflict by focuses on the methods that increase the level of psychological well-being among female employees, to improve their career sustainability, decrease job quitting rate is aim of this study.

\section{Technostress}

Technostress is a problem of adaptation that an individual experience when he or she is unable to cope with or get used to ICTs. In the organizational context, technostress is caused by individuals' attempts and struggles to deal with constantly evolving ICTs and the changing physical, social, and cognitive requirements related to their use (Tarafdar, Tu, Ragu-Nathan, \& Ragu-Nathan, 2007). Scholar Nagarajah (2016) conducted study examining personal factors on technostress and the data analysis demonstrated women experienced significantly higher levels of technostress. The research found that (a) men are more sensitive to achievement stress, (b) women are more sensitive to social rejection stress, and (c) men show higher levels of stress than women in cases of computer malfunction and network breakdowns (Riedl, Kindermann, Auinger, \& Javor, 2013). Further research by Tarafdar, Tu, Ragu-Nathan, \& Ragu-Nathan (2011) on the relation of gender to IT demonstrated that when the use of IT was voluntary, men were more inclined to use IT than women to accomplish a task, even the exact same task. Both Riedl et al.'s (2013) and Tarafdar et al.'s (2011) studies concluded that professional men or women with greater IT confidence experienced less technostress because of their confidence in their ability to understand and handle ICT issues effectively, thereby avoiding situations that create technostress. In addition to age, gender can also potentially influence technostress.

The psychological well-being level based on the impact that technostress has induced on attitudes, thoughts, and behaviors (Nimrod, 2017) of female employees, highly influence their decision of retaining or withdrawing from the IT industry. To the best of the author's knowledge, none of the technostress-related studies have examined technostress impact on psychological well-being of female employees which lead to leaky pipeline syndrome. Herein this study attempted to fill the gap by examining the relationship between technostress and psychological well-being of female talents which lead to leaky pipeline syndrome in Malaysia.

\section{Mentorship}

Ahuja (2002) points to the absence of mentoring as key among the barriers to women's retention in the IT field. By the same token, Soe \& Yakura (2008) emphasis that while mentoring is important, in order to be effective at addressing the retention of women in the IT field, mentoring programs need to be part of a broader goal of changing organizational culture and assumptions about women and technology work. In the absence of this wider change, they warn, there is a danger that negative stereotypes could be reinforced. Higgins \& Kram (2001) assert that the outcomes of mentoring programs are affected by both work environment and individual level factors. Scholars argue that a proactive facilitation of mentorships may be beneficial for development and advancement of women in IT careers. 
A group of scholars Allen, Eby, Poteet, Lentz, \& Lima (2004) and Underhill (2006) found significant relationships between workplace mentoring and career attitudes, work attitudes, and some career outcomes. Reviews of youth (D. L. DuBois, Holloway, Valentine, \& Cooper, 2002) and academic (Sambunjak et al., 2006) mentoring found an association between mentoring and both career and employment outcomes. There are also reviews linking youth (DuBois et al., 2002), academic (Dorsey \& Baker, 2004; Sambunjak, Straus, \& Marusic, 2006), and workplace (Underhill, 2006) mentoring to psychological outcomes such as positive self-image, emotional adjustment, and psychological wellbeing, although similar to our findings, several of these reviews found small effect sizes. Mentorship beneficial as research has repeatedly shown that when one's social partner and environment provides them with autonomy-support, their intrinsic motivation, quality and persistence of performance, and psychological well-being are all increased.

\section{Psychological Well-Being}

Ryff and singer's (1996; 2006) model of Psychological well-being is one of the models that come closest to explaining why physical activity can facilitate well-being. This model proposes that there are six distinct components of positive psychological functioning. In combination, these dimensions encompass a breadth of wellness that includes positive evaluations of oneself and one's past life (SelfAcceptance), a sense of continued growth and development as a person (Personal Growth), the belief that one's life is purposeful and meaningful (Purpose in Life), the possession of quality relations with others (Positive Relations With Others), the capacity to manage effectively one's life and surrounding world (Environmental Mastery), and a sense of self-determination (Autonomy).

A research by Martire et al. (2000) has shown that psychological well-being is affected by age, which is itself under the effect of increasing women's social role. A woman's family and professional responsibilities can represent an important overload if they are considered simultaneously. The traditional role of a woman as a caregiver of children, the elderly and the ill, contributes to this overload in family environment. Such responsibilities that develop in family are considered as important determinants of psychological well-being (Kowal et al., 2002; Wright \& Cropanzano, 2000). Scholar Vandenberg and Nelson (1999) explained organizational commitment, job satisfaction, and well-being at work as a predictor of the emergence of turnover intentions. Employees who have fulfilled their well-being in the workplace are more productive, contributing to the organization's goals, and low of intentions to leave (Harter, Schmidt, \& Hayes, 2002). Scholar Samad (2006) also stated the process of identifying factors influence of turnover intentions becomes important to be considered in turn lower of turnover rate in the company. Robertson and Cooper (2011) suggested employee well-being contributed towards increase of productivity and organizational performance. It will increase service to customers, profitability, and reduced employee turnover and absenteeism.

\section{Retention}

Employee retention is a process of encouraging employee to remain in the organization for long term or until a project completion (Akila, 2012). Scholar Frank, Finnegan, and Taylor, (2004, p. 13) define retention and turnover as "the effort by an employer to keep desirable workers in order to meet business objectives and turnover as the unplanned loss of workers who voluntarily leave and whom employers would prefer to keep". Employees in ICT often have long working hours, rigorous work, 
incessant pressure and pressing deadlines, which collectively challenge their work-life balance on a daily basis (Nanjamari, 2013). A review of seminal empirical studies on employee retention in ICT industry for past decades still left a need for the clarity of employee perception of antecedents of employee retention based on gender (Goy et al., 2017), psychological well-being (George, 2015), generational cohort, extrinsic, and intrinsic benefits (Babich, 2014). Therefore, this study will focus specifically on female professionals' career barriers and retention management within Malaysian ICT industry.

\section{Psychological Well-Being Mediating Variable}

Psychological well-being at work represents indicators of an individual's self- assessment of their entire work experience. It has often been depicted to represent an individual's affective state at work including experiences of work-related depression, anxiety, self-esteem, job satisfaction (Van Horn, Taris, Schaufeli, \& Schreurs, 2004). The past research of Wright and Bonett, in 2007 has proposed a link between psychological well-being and various positive workplace outcomes such as lower turnover and organizational citizenship behavior (OCB), which are extra role behaviors by the employee that benefit either the organization or an individual within the organization (Griffeth, Hom, \& Gaertner, 2000; Smith, Organ, \& Near, 1983). Psychological well-being is a complex concept that covers a range of emotional, affective and attitudinal factors that capture the overall mental health of individuals in various contexts, and measures overall psychological functioning (Wright and Cropanzano, 2000). To the best of the author's knowledge, there has been no published study to date that empirically examined psychological well-being as mediators in the relationship between female career barriers (work-family conflicts, technostress and mentorship) and job retention. The present study advances a conceptual model in which psychological well-being acts as a key mediating mechanism to examine leaky pipeline syndrome in ICT industry in Malaysia.

\section{Discussion}

This paper emphasis psychological well-being is one of the employee's need that must be met and accredited to be the best motivational factor. Positive psychological well-being can be the enablers to mitigate career barriers and to be retained in technical field for the long run. In fact, selfdetermination theory has shown how its motivational "laws" predict important organizational outcomes such as well-being (Gagné \& Deci, 2005; Vansteenkiste et al., 2007) and talent retention (Bock, 2015; Fowler, 2014) and among other critical performance indicators. Henceforth for this study, the focus is on basic psychological needs fulfilment provides a practical basis for leveraging positive change in achieving goal of female talent retention.

This paper seeks to explain the development of theoretical foundation to women psychological wellbeing literature which identified as hindrance of women career progression in technological field. The finding of the study will be important for future researchers and future job holders as it provide more knowledge and guidelines on women psychological well-being that affect women career progression especially for skill workers, professionals and managers; the ways to shatter those barriers ; as a referential material for their studies, policy makers; in creating and improving existing policies in organizations and government authorities with regard to female professionals retention in technological industry. 
Furthermore, our nation's current state of affairs, the "Envisioning Malaysia 2050: Foresight Initiative" was conceived as a guiding framework for the bold journey between Malaysia's status quo and its future destination 33 years from now. Academy of Sciences Malaysia (ASM) along with the Foresight Alliance brings experts from a myriad of subject areas to assist in building the scenarios that are plausible for Malaysia by 2050. For our desired future, it is envisioned that in 2050, Malaysia will be living in "smart communities", where we are able to live in a harmonious, sustainable and prosperous milieu. The vision will be realized by addressing three fundamental drivers: governance, wealth creation, and well-being (Academy of Sciences Malaysia, 2017). Professor Datuk Dr. Asma Ismail the president of the Academy of Sciences Malaysia, propelled that knowledge in STEM is the fuel for the future economy and enhancement of societal well-being too. In conjunction to that, this study investigates female career barriers and provide an overview of its impact on the psychological health and well- being of female professionals, with a specific focus on maintaining and enhancing their psychological balance with technology related jobs for long run.

\section{Corresponding Author}

Manimegalai Rajenderan

Putra Business School, University Putra Malaysia (UPM), Malaysia

Email: manimegalai.phd14@grad.putrabs.edu.my

\section{References}

Academy of Sciences Malaysia. (2017). Envisioning Malaysia 2050 Foresight Narrative. Retrieved from https://www.akademisains.gov.my/

Ahmad, A. (1998). Women in Malaysia. Country Briefing Paper on Women in Malaysia Women, (December), 1-81. Retrieved from http://www.adb.org/sites/default/files/institutionaldocument/32552/women-malaysia.pdf

Allen, T. D., Eby, L. T., Poteet, M. L., Lentz, E., \& Lima, L. (2004). Outcomes associated with mentoring prote'ge's: A meta-analysis. Journal of Applied Psychology, 89, 127-136.

Aryee, S., Srinivas, E. S., \& Tan, H. H. (2005). Rhythms of life: Antecedents and outcomes of workfamily balance in employed parents. Journal of Applied Psychology, 90, 132-146.

Akila, R. (2012). A Study on Employee Retention among Executives at BGR Energy Systems LTD, Chennai. International Journal of Marketing, Financial Services \& Management Research, 1(9), 18-32.

Babich, R. (2014). Relationship Between Employee Retention and Total Rewards of Extrinsic and Intrinsic Benefits. Published doctoral dissertation, University of Northcentral

Berryman, S. E. (1983). Who Will Do Science? Trend, and Their Causes in Minority and Female 
INTERNATIONAL JOURNAL OF ACADEMIC RESEARCH IN BUSINESS AND SOCIAL SCIENCES

Vol. 9, No. 2, Feb, 2019, E-ISSN: 2222-6990 C 2019 HRMARS

Representation among Holders of Advanced Degrees in Science and Mathematics. A Special Report, 132.

Benner, C (2002) Work in the New Economy. Flexible Labor Markets in Silicon Valley. Oxford: Blackwell Publishing

Baroudi, J. \& Igbaria, M. (1995). An examination of gender effects on career success of information systems employees. Journal of Management Information Systems, 11(3), 181-202. Retrieved July 14, 2012, from ABI/INFORM Global.

Bock, L. (2015). Work rules! Insights from inside Google that will transform how you live and lead. New York, NY: Grand Central.

Burke, R. J. (1984). Mentors in organizations. Group and Organization Studies, 9, 353-372.

Campbell, E. (2015). Does Mentoring Buffer Women In Science From The Effects Of Perceived Discrimination On Career Outcomes? Published doctoral dissertation, Purdue University

Cardy, L. R., \& Lengnick-Hall, L. M. (2011). Will they stay or will they go? Exploring a customeroriented approach to employee retention. Journal of Business Psychology, 26, 213-217. doi:10.1007/s10869-011-9223-8

Deci, E. L., \& Ryan, R. M. (2008). Hedonia, eudaimonia, and well-being: An introduction. Journal of Happiness Studies, 9,1-11.

DuBois, D. L, Holloway, B. E., Valentine, 3. C, \& Cooper, H. (2002). Effectiveness of mentoring programs for youth: A meta-analytic review. American Journal of Community Psychology, 30(2) $f$ 157-1

Frank, F.D., Finnegan, R.P. and Taylor, C.R. (2004), "The race for talent: retaining and engaging workers in the 21st century", Human Resource Planning, Vol. 27 No. 3, pp. 12-25.

Frone, M. R., Russell, M., \& Cooper, M. L. (1992). Antecedents and outcomes of work- family conflict: Testing a model of the work-family interface. J. Appl. Psychology, 77, 65-78

Fowler, S. (2014). Why motivating people doesn't work ... and what does: The new science of leading, energizing, and engaging. Oakland, CA: Berrett-Koehler.

Gagne, \& Deci, E. L. (2005). Self-determination theory and work motivation. Abstract and Applied Analysis, 2005(June 2004), 331-362. https://doi.org/10.1155/2015/635035

George, C. (2015). Retaining professional workers: what makes them stay? Employee Relations, 
INTERNATIONAL JOURNAL OF ACADEMIC RESEARCH IN BUSINESS AND SOCIAL SCIENCES

Vol. 9, No. 2, Feb, 2019, E-ISSN: 2222-6990 C 2019 HRMARS

37(1), 102-121. https://doi.org/10.1108/ER-10-2013-0151

Gillet, N., Fouquereau, E., Forest, H., Brunault, P., \& Colombat, P. (2012). The impact of organizational factors on psychological needs and their relations with well-being. Journal of Business Psychology, 27, 437-450.

Greenhaus, J. H., \& Beutell, N. J. (1985). Sources of confl ict between work and family roles. Academy of Management Review, 10, 76-88.

Griffeth, R. W., Hom, P. W., \& Gaertner, S. (2000). A meta-analysis of antecedents and corre- lates of employee turnover: Update, moderator tests, and research implications for the next millennium. Journal of Management, 26(3), 463-488.

Greenhaus, J. H., \& Powell, G. N. (2003). When work and family collide: Deciding between competing role demands. Organizational Behavior \& Human Decision Processes, 90(2), 291.

Goy, S. C., Wong, Y. L., Low, W. Y., Noor, S. N. M., Fazli-Khalaf, Z., Onyeneho, N., GinikaUzoigwe, A. (2017). Swimming against the tide in STEM education and gender equality: a problem of recruitment or retention in Malaysia. Studies in Higher Education, $0(0), 1-17$. Retrieved from https://doi.org/10.1080/03075079.2016.1277383

Gurer, D., \& Camp, T. (2002). The ACM-W literature review on women in computing. ACMSIGCSE Bulletin, 34(2), 121-127. Retrieved March 12, 2008 from The Guide to Computing Literature database.

Haar, J. M. (2004). Work-family conflict and turnover intention: Exploring the moderation effects of perceived work-family support. New Zealand Journal of Psychology, 33, 35-40. Retrieved from doi:10.1037//0021-9010.76.4.560

Higgins, M.C. and Kram, K.E. (2001), "Reconceptualizing mentoring at work: a developmental network perspective", Academy of Management Review, Vol. 26, pp. 264-88.

Higgins, C., Duxbury, L., \& Irving, R. H. (1992). Work-family conflict in the dual- career family. Organizational Behavior and Human Decision Processes, 51, 51-75.

Harter, J. K., Schmidt, F. L., \& Hayes, T. L. (2002). Business-unit-level relationship between employee satisfaction, employee engagement, and business outcomes: A meta-analysis. Journal of Applied Psychology, 87(2), 268-279. https://doi.org/10.1037/0021-9010.87.2.268

Howell, R. T., Chenot, D., Hill, G., \& Howell, C. J. (2011). Momentary Happiness: The Role of Psychological Need Satisfaction. Journal of Happiness Studies, 12(1), 1-15. https://doi.org/10.1007/s10902-009-9166-1 
INTERNATIONAL JOURNAL OF ACADEMIC RESEARCH IN BUSINESS AND SOCIAL SCIENCES

Vol. 9, No. 2, Feb, 2019, E-ISSN: 2222-6990 C 2019 HRMARS

Holm, J, Lahteenmaki, S, Salmela, H and Suomi, R (2002) 'Best Practices of ICT Workforce Management: A Comparable Research Initiative.' Journal of European Industrial Training, 26 (6/7): 333-341.

Hyde, A (2003) Working in Silicon Valley: Economic and Legal Analysis of a High Velocity Labor Market. New York: Armonk.

Ivan T. Robertson, Cary L. Cooper, (2010) "Full engagement: the integration of employee engagement and psychological well-being", Leadership \& Organization Development Journal, Vol. 31 Issue: 4,pp. 324-336, doi: 10.1108/01437731011043348

Kyndt, E., Dochy, F., Michielsen, M., \& Moeyaert, B. (2009). Employee retention: Organisational and personal perspectives. Vocations and Learning, 2(3), 195-215. https://doi.org/10.1007/s12186-009-9024-7

Kram KE (1983) Phases of mentor relationships. Academy of Management Journal 26 608-625. Kowal, A., Kramer, L., Krull, J. L., \& Crick, N. R. (2002). Children's perceptions of the fairness of parental preferential treatment and their socioemotional well- being. Journal of Family Psychology, 16(3), 297-306.

Kyndt, E., Dochy, F., Michielsen, M., \& Moeyaert, B. (2009). Employee retention: Organisational and personal perspectives. Vocations and Learning, 2(3), 195-215.

Lehr, J. L. (2001). Athena Unbound: The Advancement of Women in Science and Technology. BioScience, 51(6), 504. https://doi.org/10.1641/0006-3568(2001)051[0504:AUTAOW]2.0.CO;2

Louise Soe, Elaine K. Yakura. 2008. What's Wrong with the Pipeline? Assumptions about Gender and Culture in IT Work. Women's Studies 37:3, 176-201.

MK Ahuja (2002). Women in the information technology profession: a literature review, synthesis and research agenda. Accounting European Journal of Information Systems (2002) 11, 20-34. DOI: $10.1057 /$ palgrave/ejis/3000417

Martire, L. M., Stephens, M. A. P., \& Townsend, A. L. (2000). Centrality of women's multiple roles: Beneficial and detrimental consequences for psychological well-being. Psychology and aging, 15(1), 148-156.

Maitland A (2001) A long-term solution to the IT skills shortage. Financial Times (22 February), 9.

Ministry of Education Malaysia (MOE). (2016). Sharing Malaysian Experience in Participation of Girls in Stem. May, 2016, (3). 
INTERNATIONAL JOURNAL OF ACADEMIC RESEARCH IN BUSINESS AND SOCIAL SCIENCES

Vol. 9, No. 2, Feb, 2019, E-ISSN: 2222-6990 C 2019 HRMARS

Ministry of Higher Education (MOHE) (2010 \& 2016). Graduate Tracer Study (2010 \& 2016) Malaysia Digital Economy Corporation (MDEC) (2014) MSC Malaysia Talent Supply-Demand Study $2013-2017$

Ministry of Women, Family and Community Development Malaysia (2013). Study to Support The Development of national policies and Programmes to Increase and Retain the Participation of Women in the Malaysian Labour Force

Ministry of Science Technology and Innovation (MOSTI) (2013). ICT Strategic Review 2013/14: The Digital Opportunity

McKeown, L, Veenhof, B and Corman, J (2008) 'Profi ling Internet use among workers in the information and communications technologies sector.' Innovation Analysis Bulletin, 10, (1): 22.

Nelson DL, Quick JC. Professional women: Are distress and disease inevitable? Academy of Management Review, 1985: 10: 206-218.

Niederman, F and Ferratt, T W (2006) IT Workers: Human Capital Issues in a Knowledge- Based Environment. Greenwich/Conn.: Information Age Publishing (IAP).

Nanjamari, K. (2013). Job satisfaction amongst information technology (IT) employees in Bangalore city a sociological approach. Journal of Humanities and Social Science, 6(6), 35-40. Retrieved from http://www.iosrjournals.org

Nimrod, G. (2017). Technostress: measuring a new threat to well-being in later life. Aging and Mental Health, 7863(June), 1-8. https://doi.org/10.1080/13607863.2017.1334037

O'Driscoll, M. P., Brough, P., \& Kalliath, T. J. (2004). Work/family conflict, psychological well-being, satisfaction, and social support: a longitudinal study in New Zealand. Equal Opportunity International, 23(1), 36-56.

Owusu-Ansah, S., Azasoo, J. Q., \& Adu, I. N. (2016). Understanding the effects of techno-stress on the performance of banking staff. International Journal of Business Continuity and Risk Management, 6, 222-237. doi:10.1504/IJBCRM.2016.079010

Parasuraman, S., Greenhaus, J. H., Rabinowitz, S. R., Bedeian, A. G., \& Mossholder, K. W. (1989). Work and family variables as mediators of the relationship between wives' employment and husbands' well-being. Academy of Management Journal, 32, 185-201. 
INTERNATIONAL JOURNAL OF ACADEMIC RESEARCH IN BUSINESS AND SOCIAL SCIENCES

Vol. 9, No. 2, Feb, 2019, E-ISSN: 2222-6990 C 2019 HRMARS

Pfleeger SL and Mertz N (1995) Executive mentoring: what makes it work? Communications of the ACM 38,63-73.

Ross, P K (2009) 'New Technology and Work in the Australian Telecommunications Sector: What Role for Technicians?' Labour and Industry, 20 (1): 45-66.

Riedl, R., Kindermann, H., Auinger, A., \& Javor. A. (2013). Computer breakdown as a stress factor during task completion under time pressure: Identifying gender difference based on shin conductance. Advances in Human-Computer Interaction, 2013, 1-8. doi:10.1155/2013/420169

Ryff, C. D., \& Singer, B. (1996). Psychological well-being: meaning, measurement, and implications for psychotherapy research. Psychother. Psychosom., 65, 14-23.

Ryff, C. D., \& Singer, B. H. (2006). Best news yet on the six-factor model of well- being. Social Science Research, 35(4), 1103-1119.

Sambunjak, D., Straus, S. E., \& Marusic, A. (2006). Mentoring in academic medicine. Journal of the American Medical Association, 296, 1103-1115.

Samad, S. (2006). Assessing the effects of work and family related factors on women well- being. Journal of American Academy of Business, 9, 52-57.

Smith, C. A., Organ, D. W., \& Near, J. P. (1983). Organizational citizenship behavior: Its nature and antecedents. Journal of Applied Psychology, 68(4), 653-663.

Smith, V., \& Swamy, G. (2016). Women In Tech : Addressing the Root Causes of Attrition. Women of the Channel. Retrieved from https://witi.berkeley.edu/Leadership-Roundtable/

TalentCorp Malaysia \& ACCA. (2013). Retaining women in the workforce, (86), 1-40.

Tarafdar, M., Tu, Q., Ragu-Nathan, B., \& Ragu-Nathan, T. (2007). The impact of technostress on role stress and productivity. Journal of Management Information Systems, 24(1), 301-328. https://doi.org/10.2753/MIS0742-1222240109

Tremblay, D-G (2003) 'New types of careers in the knowledge economy? Networks and boundaryless jobs as a career strategy in the ICT and multimedia sector.' Canada Research Chair on the Socio-Organisational Challenges of the Knowledge Economy: Research Note no 2003-12A. Québec: Télé-université, University of Québec.

Nagarajah, B.A. (2016). The Influence Of Professional Training And Personal Factors On Technostress: A Correlational Study. Published doctoral dissertation, University of Capella

The National ICT Association of Malaysia (2017). ICT Job market outlook in Malaysia 
INTERNATIONAL JOURNAL OF ACADEMIC RESEARCH IN BUSINESS AND SOCIAL SCIENCES

Vol. 9, No. 2, Feb, 2019, E-ISSN: 2222-6990 C 2019 HRMARS

The National ICT Association of Malaysia. (2017). ICT Job market outlook in Malaysia. ICT Job Market Outlook in Malaysia, 36. Retrieved from http://www.pikom.org.my/2015/ICT_Job_Market_Outlook/090715ictjobmarket2015_Final.pdf

Trauth, E. M., Quesenberry, J. L., \& Huang, H. (2006). Cross-cultural influences on women in the IT workforce. Proceedings of the 2006 ACM SIGMIS CPR Conference on Computer Personnel Research Forty Four Years of Computer Personnel Research: Achievements, Challenges \& the Future - SIGMIS CPR '06, 12. https://doi.org/10.1145/1125170.1125178

Vandenberg, R. J., \& Nelson, J. B. (1999). Disaggregating the motives underlying turnover intentions: When do intentions predict turnover behavior? Human Relations, 52(10), 1313-1336.

Van Horn, J.E., Taris, T.W., Schaufeli, W.B. and Schreurs, P.J.G. (2004), "The structure of occupational

wellbeing: a study among Dutch teachers", Journal of Occupational and Organizational Psychology, Vol. 77 No. 3, pp. 365-375.

Vansteenkiste, M., Neyrinck, B., Niemiec, C. P., Soenens, B., De Witte, H., \& den Broeck, A. V. (2007). On the relations among work value orientations, psychological need satisfaction and job outcomes: A self-determination theory approach. Journal of Occupational and Organizational Psychology, 80, 251-277.

Woszcynski, A., Myers, M., \& Beise, C. (2003). Women in information technology. In M. Igbaria (Ed.), Strategies for managing IS/IT personnel (165-193). Hershey, PA: Idea Group Inc.

Wright, T. A., \& Cropanzano, R. (2000). Psychological well-being and job satisfaction as predictors of job performance. Journal of Occupational Health Psychology, 5(1), 84.

Wright, T. A., \& Bonett, D. G. (2007). Job satisfaction and psychological well-being as nonadditive predictors of workplace turnover. Journal of Management, 33(2), 141-160. 